\title{
DISTRIBUTION OF BENIGN LARYNGEAL TUMORS IN CORRELATION WITH DURATION OF CIGARETTE SMOKING
}

\author{
Slaviša Radosavljević1, Miško Živić2,3, Marija Conić-Miletić ${ }^{2}$, \\ Biljana Kostić-Inić ${ }^{4}$
}

\begin{abstract}
The tumor cells of benign laryngeal tumors resemble the normal cells from which they originated; however, the ration between these cells is disturbed and does not serve any purpose. Benign tumors are widespread to the extent that practically each person has some benign tumor. The largest number of benign tumors remain benign a lifetime.

Sixty-two persons were diagnosed with benign laryngeal tumors, of which $42(67.7 \%)$ were male and $20(32.3 \%)$ female. Statistically significant difference in duration of smoking with regard to the sex of the patients was not found in the population diagnosed with benign laryngeal tumors $\left(\chi^{2}=10.32 ; p=0.243\right)$.

There were 62 persons diagnosed with benign laryngeal tumors, of which $42(67.7 \%)$ were male and $20(32.3 \%)$ female. The ratio between male and female population diagnosed with benign laryngeal tumors was 2:1.

The largest number of men were in the sixt and seventh decade of life, whereas the majority of the female population was in the fifth and sixth decade of life. Statistically significant difference in the distribution of benign laryngeal tumors by decades of life with regard to the sex of the patients was not found $\left(\chi^{2}=4,39 ; p=0,624\right)$. Benign laryngeal tumors can be of neoplastic origin (papilloma, fibroma); they can also be the consequence of allergy or some metabolic disorder (polyp), or the consequence of internal or external traumas (vocal cord nodules, granulation tissue after intubation) or smoking. Acta Medica Medianae 2017;56(2):13-17.
\end{abstract}

Key words: larynx, benign tumor, smoking

Primary Healthcare Center "Obilić"

ENT Clinic, Clinical Center Niš ${ }^{2}$

University of Niš, Faculty of Medicine, Niš, Serbia ${ }^{3}$

Internal Clinic of the Clinical Hospital Center Priština-Gračanica ${ }^{4}$

Contact: Slaviša Radosavljević

Primary Healthcare Center Obilić,

15000 Obilić

E-mail: radosavljevicslavisa@yahoo.com

\section{Introduction}

The tumor cells of benign laryngeal tumors resemble the normal cells from which they originated; however, the ration between these cells is disturbed and does not serve any purpose. Benign tumors are widespread to the extent that practically each person has some benign tumor. The largest number of benign tumors remain benign a lifetime.

Polyps, nodules, and cysts of the vocal cords are common benign proliferative lesions (1).

Vocal cord nodules differ by size and shape (2). Vocal cord nodules appear due to excessive and incorrect use of voice (3).
Tumors are defined as growths in the human body that cross the normal boundaries of the human organs. The basic characteristic of tum-ors is that they independently grow and develop on organs and tissues. However, not all the tumors grow and develop in the same way. One group of them grow retaining the same shape and distri-bution of cells of the organ or tissue where they appeared, remaining thus on that organ, causing, apart from mechanical ones, no other disturbances in the body. That is why these tumors are called benign tumors. If they cause mechanical or esthetic problems, they can be easily surgically removed, with no further consequences.

Tumor is defined as local, autonomous, atypical, uncontrolled and harmful growth of a tissue. Being local means that tumor begins to grow on a limited part of the tissue in the form of one or several growths; atypical means that the tumor differs in terms of its structure from the tissue from which it originated; autonomous means that the tumor develops independently from the rest of the tissue and the organism; uncontrolled growth indicates that the tumor grows without being controlled by the organism. Tumor forms are also different. 
After surgical intervention, setting the histopathological diagnosis, and confirmation of tumor benignity, phoniatrics should follow.

\section{Research subjects}

The subjects of this research were patients of the ENT Clinic, Clinical Center Niš. Prospective inve-stigation included 62 patients with benign laryngeal tumors.

\section{Aims}

By performing a prospective analysis of the clinical material of the ENT Clinic in Nis and biopsy specimens from the Center for Pathology and Pathological Anatomy Niš, the aims of the research were to determine:

1. The incidence of benign laryngeal tumors.

2. Age and gender distribution of patients with benign laryngeal tumors.

3. The incidence of benign laryngeal tumors in correlation with duration of 20 cigarette smoking.

\section{Methods} were used:

During the research, the following methods

1. Clinical examination (history taking, indirect laryngoscopy)

2. Laryngeal videostroboscopy

3. Laryngomicroscopy

\section{Pathohistological diagnostics}

Laryngomicroscopy is a dignostic procedure performed by means of a surgical microscope. It is best performed when ptient is under general endotracheal anesthesia.

If, due to the tumor size in the larynx, endotracheal anesthesia is impossible, tracheotomy is indispensable.

Laryngomicroscopy is the safest method to determine the mucosal spread of the present tumors, with concurrent taking a sample for the histopato-logical examination.

Using this method, Morgagni's ventricle can be visualized by lifting and moving aside the ventricular fold.

\section{Results}

\section{Benign tumors}

It was found that 62 persons were diagnosed with benign laryngeal tumors, of which 42 $(67.7 \%)$ were male and $20(32.3 \%)$ female.

Statistically significant difference was not determined between smokers and non-smokers diagnosed with benign tumor with regard to the gender $\left(\chi^{2}=2.60, p=0.106\right)$. The largest number of smokers smoked for more than 20 years. Duration of smoking was not statistically significantly different with regard to the sex of examinees diagnosed with benign laryngeal cancer

Table 1. Duration of cigarette smoking in patients with benign laryngeal tumors

\begin{tabular}{|c|c|c|c|c|c|c|c|c|c|c|c|}
\hline \multicolumn{12}{|c|}{ Duration of cigarette smoking } \\
\hline Sex & $\begin{array}{c}\text { Non- } \\
\text { smokers }\end{array}$ & $\begin{array}{c}5 \\
\text { years }\end{array}$ & $\begin{array}{c}10 \\
\text { years }\end{array}$ & $\begin{array}{c}15 \\
\text { years }\end{array}$ & $\begin{array}{c}20 \\
\text { years }\end{array}$ & $\begin{array}{c}25 \\
\text { years }\end{array}$ & $\begin{array}{c}30 \\
\text { years }\end{array}$ & $\begin{array}{c}35 \\
\text { years }\end{array}$ & $\begin{array}{c}40 \\
\text { years }\end{array}$ & $\begin{array}{c}45 \\
\text { years }\end{array}$ & $\begin{array}{c}50 \\
\text { years }\end{array}$ \\
\hline $\begin{array}{c}\text { Men } \\
\mathrm{n}(\%)\end{array}$ & $\begin{array}{c}7 \\
(50.0)\end{array}$ & $\begin{array}{c}1 \\
(50.0)\end{array}$ & $\begin{array}{c}0 \\
(0.0)\end{array}$ & $\begin{array}{c}4 \\
(100.0)\end{array}$ & $\begin{array}{c}7 \\
(70.0)\end{array}$ & $\begin{array}{c}1 \\
(50.0)\end{array}$ & $\begin{array}{c}6 \\
(75.0)\end{array}$ & $\begin{array}{c}4 \\
(100.0)\end{array}$ & $\begin{array}{c}6 \\
(77.8)\end{array}$ & $\begin{array}{c}3 \\
(100.0)\end{array}$ & $\begin{array}{c}3 \\
(100.0)\end{array}$ \\
\hline $\begin{array}{c}\text { Women } \\
\mathrm{n}(\%)\end{array}$ & $\begin{array}{c}7 \\
(50.0)\end{array}$ & $\begin{array}{c}1 \\
(50.0)\end{array}$ & $\begin{array}{c}1 \\
(100.0)\end{array}$ & $\begin{array}{c}3 \\
(0.0)\end{array}$ & $\begin{array}{c}3 \\
(30.0)\end{array}$ & $\begin{array}{c}1 \\
(50.0)\end{array}$ & $\begin{array}{c}2 \\
(25.0)\end{array}$ & $\begin{array}{c}0 \\
(0.0)\end{array}$ & $\begin{array}{c}2 \\
(0.0)\end{array}$ & $\begin{array}{c}0 \\
(0.0)\end{array}$ & $\begin{array}{c}0 \\
(0.0)\end{array}$ \\
\hline $\begin{array}{l}\text { Total } \\
\mathrm{n}(\%)\end{array}$ & $\begin{array}{c}14 \\
(100.0)\end{array}$ & $\begin{array}{c}2 \\
(100.0)\end{array}$ & $\begin{array}{c}1 \\
(100.0)\end{array}$ & $\begin{array}{c}7 \\
(100.0)\end{array}$ & $\begin{array}{c}10 \\
(100.0)\end{array}$ & $\begin{array}{c}2 \\
(100.0)\end{array}$ & $\begin{array}{c}8 \\
(100.0)\end{array}$ & $\begin{array}{c}4 \\
(100.0)\end{array}$ & $\begin{array}{c}8 \\
(100.0)\end{array}$ & $\begin{array}{c}3 \\
(100.0)\end{array}$ & $\begin{array}{c}3 \\
(100.0)\end{array}$ \\
\hline
\end{tabular}

Table 2. Distribution of benign laryngeal tumors by decades with regard to the sex of patients

\begin{tabular}{|c|c|c|c|c|c|c|c|c|}
\hline \multirow{2}{*}{ Sex } & \multicolumn{7}{|c|}{ Decades } & \multirow{2}{*}{$\begin{array}{l}\text { Total } \\
\mathrm{n}(\%)\end{array}$} \\
\hline & II & III & IV & $\mathrm{V}$ & VI & VII & VIII & \\
\hline $\begin{array}{c}\text { Men } \\
\mathrm{n}(\%)\end{array}$ & $\begin{array}{c}1 \\
(100.0) \\
\end{array}$ & $\begin{array}{c}1 \\
(50.0) \\
\end{array}$ & $\begin{array}{c}7 \\
(36.6) \\
\end{array}$ & $\begin{array}{c}8 \\
(57.1) \\
\end{array}$ & $\begin{array}{c}11 \\
(64.7) \\
\end{array}$ & $\begin{array}{c}13 \\
(86.7) \\
\end{array}$ & $\begin{array}{c}1 \\
(50.0) \\
\end{array}$ & $\begin{array}{c}42 \\
(67.7) \\
\end{array}$ \\
\hline $\begin{array}{l}\text { Women } \\
\mathrm{n}(\%)\end{array}$ & $\begin{array}{c}0 \\
(0.0)\end{array}$ & $\begin{array}{c}1 \\
(50.0)\end{array}$ & $\begin{array}{c}4 \\
(63.4)\end{array}$ & $\begin{array}{c}6 \\
(42.9)\end{array}$ & $\begin{array}{c}6 \\
(35.3)\end{array}$ & $\begin{array}{c}2 \\
(13.3)\end{array}$ & $\begin{array}{c}1 \\
(50.0)\end{array}$ & $\begin{array}{c}20 \\
(32.3)\end{array}$ \\
\hline $\begin{array}{l}\text { Total } \\
\mathrm{n}(\%)\end{array}$ & $1(100.0)$ & $\begin{array}{c}2 \\
(100.0) \\
\end{array}$ & $\begin{array}{c}11 \\
(100.0)\end{array}$ & $14(100.0)$ & $17(100.0)$ & $15(100.0)$ & $2(100.0)$ & $62(100.0)$ \\
\hline
\end{tabular}

$\left(\chi^{2}=10.32, p=0.243\right)$.

The largest number of males with benign laryngeal tumors were in the sixth and seventh decade of life. As for the female patients, they were in the fifth and sixth decade of life. Statistically significant difference in the distribution of 
benign tumors by decades with regard to the sex of the patients was not found $\left(\chi^{2}=4.39, \mathrm{p}=\right.$ $0.624)$.

\section{Discussion}

Predisposing factors consist of age, gender, anatomic characteristics, and fragility of the laryngo tracheal mucosa (4) Sixty-two persons were diagnosed with benign laryngeal tumors, of which $42(67.7 \%)$ were male and $20(32.3 \%)$ female. The majority of males smoked for 20 and 40 years, whereas women mostly smoked for 15 and 20 years. Statistically significant difference in duration of smoking with regard to the sex of the patients was not found in the population diagnosed with benign laryngeal tumors $\left(\chi^{2}=10.32 ; p=0.243\right)$.

In the examined group of patients diagnosed with benign laryngeal tumors in the second decade of life there was one man or $1.61 \%$; in the third decade of life, there was one man or $1.61 \%$, and one woman or $1,61 \%$; in the fourth decade there were seven men or $11.29 \%$ and four women or $6.45 \%$, i.e. 11 patients in total or $17.74 \%$; in the fifth decade of life, there were eight men or $12.90 \%$ and six women or $9.68 \%$, i.e. 14 patients in total or $22.58 \%$; in the sixth decade, there were 11 men or $17.74 \%$ and six women or $9.68 \%-17$ patients in total or $27.42 \%$; in the seventh decade of life, there were 13 men or $20.97 \%$ and 2 women or $3.23 \%$, i.e. 15 patients in total or 24.19 $\%$; in the eight decade of life, there was one man or $1.61 \%$ and one woman or $1,61 \%-2$ patients in total or $3.23 \%$. There were 62 persons diagnosed with benign laryngeal tumors, of which 42 (67.7\%) were male and $20(32.3 \%)$ female. The ratio between male and female population diagnosed with benign laryngeal tumors was $2: 1$. The largest number of men were in the sixt and seventh decade of life, whereas the majority of the female population was in the fifth and sixth decade of life. Statistically significant difference in the distribution of benign laryngeal tumors by decades of life with regard to the sex of the patients was not found $\left(\chi^{2}\right.$ $=4.39 ; p=0.624$ ).

Tumors of the larynx can be benign or malignant. Both groups of tumors manifest with similar symptoms and can coexist. Symptoms depend on the size and location of the tumor, irrespective of the tumor type.

Benign laryngeal tumors can be of neoplastic origin (papilloma, fibroma); they can also be the consequence of allergy or some metabolic disorder (polyp), or the consequence of internal or external traumas (vocal cord nodules, granulation tissue after intubation) or smoking.

Polyps, nodules, and cysts of the vocal cords are common benign proliferative lesions (1).
Vocal cord nodules differ by size and shape (2). Vocal cord nodules appear due to excessive and incorrect use of voice (3). The benign laryngeal lesion produces symptoms which can vary from mild hoarseness to life-threatening stridor. Tumors of the larynx are usually detected early due to dysphonia, i.e. change in voice, but the early and precise diagnosis of cancer of the larynx is still a challenge. Videostroboscopic examination did not reveal resolution of the initial pathology in any case (5-7). Once the diagnosis of a benign granular cell tumor is confirmed, complete surgical resection be comes the appropriate treatment. We performed bronchoscopy when our patient developed chronic cough with stridor. As the final solution tracheostomy had to be chosen for maintaining $\mathrm{O} 2$ saturation as facilities were limited (8-10).

Benign tumors are clearly limited, grow slowly, thus exerting pressure on the adjacent tissue. Some-times, they metastasize. They are usually capsulated. According to Gavrić, they are not the cause of death of the host. According to the modified Borst's definition, "tumor is local, atypical, autonomous, constant and purposeless growth of a tissue". Hoarseness and dysphonia are usually the result of the vocal cord polyps (11).

\section{Conclusion}

1. Statistically significant difference among smokers and non-smokers diagnosed with benign laryngeal cancer with regard to the sex was not found $\left(\chi^{2}=2,60, p=0,106\right)$.

2. Statistically significant difference in duration of smoking was not found in the population diagnosed with benign laryngeal cancer with regard to the sex of patients $\left(\chi^{2}=10,32\right.$, $p=0,243)$.

3. The largest number of males with benign laryngeal tumors were in the sixth and seventh decade of life.

4. Statistically significant difference in the distribution of benign tumors by decades with regard to the sex of the patients was not found $\left(\chi^{2}=4,39, p=0,624\right)$.

5. The largest distribution of benign laryngeal tumors is in the sixth decade, followed by the seventh, fifth, and fourth decade of life.

6. The largest number of patients diagnosed with benign laryngeal tumor smoked for more than 20 years.

7. In males, benign laryngeal tumors prevail in the sixth and seventh decade of life, whereas in females they usually appear in the fifth and sixth decade of life. 


\section{References}

1. Huang X, Zhang G, Liu X, Wang T, Zhu L. Detection of benign proliferative lesions on vocal cords with voice handicap index. Exp Ther Med 2012; 4(4):733-5. [CrossRef] [PubMed]

2. Rubin HJ. VOCAL NODULES-A high-speed photographic analysis: notes on treatment. Calif Med 1961; 95(6):374-7. [PubMed]

3. Li NYK, Dailey S, Thibeault SL. Assessment of fine needle aspiration feasibility and specimen adequacy for molecular diagnostics of benign vocal fold lesions. Laryngoscope 2013; 123(4):960-5. [CrossRef] [PubMed]

4. Keiser GJ, Bozentka NE, Gold BD. Laryngeal granuloma: a complication of prolonged endotracheal intubation. Anesthesia Progress 1991; 38(6):232-4. [PubMed]

5. Schindler A, Mozzanica F, Ginocchio D, Maruzzi P, Atac M, Ottaviani F. Vocal improve ment after voice therapy in the treatment of benign vocal fold lesions. Acta Otorhinolaryngo 2012; 32(5): 304-8. [PubMed]
6. Singhal $P$, Bhandari $A$, Chouhan $M$, Sharma MP, Sharma S. Benign tumors of the larynx: a clinical study of 50 cases. Indian J Otolaryngol 2009; 61(Suppl 1):26-30. [CrossRef] [PubMed]

7. Sharma DK, Sohal BS, Bal MS, Aggarwal S. Clinicopathological study of 50 cases of tumours of larynx. Indian J Otolaryngol 2013; 65(Suppl 1):2935. [CrossRef] [PubMed]

8. Shin B, Kim M, Yoo H, Kim SJ, Lee JE, Jeon K. Tracheobronchial polyps following thermal inhalation injury. Tuberc Respir Dis (Seoul) 2014;76(5):237-9. [CrossRef] [PubMed]

9. Park JH, Do NY, Cho SI, Choi JY. Granular cell tumor on larynx. Clin Exp Otorhinolar 2010; 3(1):52-5. [CrossRef] [PubMed]

10. Lathadevi HT, Guggarigoudar SP. Difficulties in management of a sessile subglottic polyp. J Clin Diagn Res 2015; 9(12): MD01-02. [CrossRef] [PubMed]

11. Chu MP, Chu KPM, Fung K. Vocal polyps in Tourette syndrome. J Mov Disord 2011; 4(2):80-1. [CrossRef] [PubMed] 


\title{
DISTRIBUCIJA BENIGNIH TUMORA LARINKSA U KORELACIJI SA PUŠAČKIM STAŽOM
}

\author{
Slaviša Radosavljević ${ }^{1}$, Miško Živić2,3, Marija Conić-Miletić ${ }^{2}$, \\ Biljana Kostić-Inić4
}

\author{
Dom zdravlja „Obilić”, Obilić, Srbija ${ }^{1}$ \\ ORL klinika Klinički centar, Niš, Srbija ${ }^{2}$ \\ Univerzitet u Nišu, Medicinski fakultet, Niš, Srbija ${ }^{3}$ \\ Interna klinika KBC Priština-Gračanica, Gračanica, Srbija ${ }^{4}$ \\ Kontakt:Slaviša Radosavljević \\ Dom zdravlja "Obilić”, 15000 Obilić, Srbija \\ E-mail: radosavljevicslavisa@yahoo.com
}

Tumorske ćelije benignih tumora larinksa liče na normalne ćelije od kojih su nastale, ali je odnos ovih ćelija poremećen i ne služi određenoj funkciji. Benigni tumori su toliko rasprostranjeni, da praktično svaki čovek ima po neki benigni tumor. Najveći broj benignih tumora ostaje dobroćudan u toku celog života.

Ispitali smo 62 osobe sa benignim tumorom larinksa, od kojih su $42(67,7 \%)$ muškarca i $20(32,3 \%)$ žena. Nije utvrđena statistička značajnost u odnosu na pušački staž kod obolelih od benignih tumora larinksa u odnosu na pol.

Od 62 bolesnika $(100 \%), 42(67,7 \%)$ su muškarci, a $20(32,3 \%)$ je žena. Broj obolelih muškaraca od benignih tumora larinksa u odnosu na žene je $2: 1$.

Najveći broj muškaraca se nalazi u VI i VII dekadi života, a žena u V i VI deceniji. Nije utvrđena statistički značajna razlika u distribuciji benignih tumora larinksa po dekadama u odnosu na pol $\left(\chi^{2}=4,39 ; p=0,624\right)$.

Benigni tumori larinksa mogu biti neoplastičnog porekla (papilom, fibrom), mogu biti posledica alergije ili poremećaja metabolizma (polipi), a mogu biti i posledica unutrašnjih ili spoljašnjih trauma (»pevački čvorić«, granulacije posle intubacije) ili pušenja. Acta Medica Medianae 2017;56(2):13-17.

Ključne reči: larinks, benigni tumor, pušenje 